\title{
Islamic Legal Protection of Child's Rights in Polygamous Marriage in Indonesia
}

\author{
Mulia Siregar ${ }^{1}$, Fatimah Zuhrah ${ }^{2}$, Muhammad Jailani ${ }^{3}$ \\ ${ }^{1}$ Department of Psychology, University of Medan Area \\ ${ }^{2}$ State Islamic University of North Sumatra, Indonesia \\ ${ }^{3}$ Department of Sociology of Religion, State Islamic University of North Sumatra, Indonesia \\ muliasiregar0204@gmail.com¹, fatimahzuhrah@yahoo.com ${ }^{2}$, muhammad.jailani2011@gmail.com ${ }^{3}$
}

\begin{abstract}
The Indonesian Marriage Law Act Number 1/1974, and the Compilation of Islamic Law (KHI) regulate the constitutional law of polygamous marriage in Indonesia. The act states that the basic principle of marriage in Indonesia is monogamy. The act also says that the husband must show evidence telling his ability to fulfill his family needs. The study on these issues conducted in Indonesia is a part of the Indonesia Islamic family law. The neglected protection of the child's rights in a family needs to be escorted through imposing the rules concerning it. This study aims to find out the implementation of the protection of child rights in Islamic law on polygamous marriage. This research employed a qualitative method with a socio-legal study case approach. The result of the study showed first, there is always a problem in the matter of the child's rights that should be fulfilled by polygamist fathers that have to be protected. Second, the rights of children in polygamous marriage cannot be fulfilled equally especially in unrecorded polygamous marriages. Third, there is uncertainty in the marriage law related to the maturity of children who are still under the protection of parents, where this uncertainty will make it difficult to implement the law. Basically, the protection of children in polygamous marriages has been regulated in the Islamic Marriage Law in Indonesia. However, there are still many gaps in Islamic legal protection in child protection in polygamous marriages, plus there are still many people who do not comply and ignore it.
\end{abstract}

Key Word

Islamic legal protection, Child's Rights, Polygamous Marriage

Article Received: 10 August 2020, Revised: 25 October 2020, Accepted: 18 November 2020

\section{Introduction}

Islamic jurisprudence experts have written about the permissibility and requirements of polygamy and its effectiveness and benefit. Still, every opinion expressed by the experts always reflects certain tendencies and a variety of emotional descriptions from one author to another. From its legal aspect, polygamy is a legal action in the category of permissibility (mubah). At the same time, there are very few verses in the Koran that discuss the permissibility of polygamy.

In Indonesia, the polygamous marriage is regulated in the Act Number $1 / 1974^{1}$, and the Compilation of Islamic Law $(\mathrm{KHI})^{2}$. In Act

${ }^{1}$ UU no. 1 of 1974 effective from 1 October 1975 consisting of 14 chapters and 67 articles.

${ }^{2}$ The Compilation of Islamic Law (KHI) was enacted by Presidential Instruction No. 1 year 1991, June 10, 1991, consists of three books, book I on Marriage Law, book II on Inheritance Law,
Number 1/1974 explicitly states that the principle of marriage is monogamy. However, the law does not rule out polygamy for a husband with certain conditions, and legally permitted, with a maximum limit of 4 wives. The provisions of this law require permission from the court. Conversely, without a polygamy certificate that has been issued by the court, the polygamous marital status has no legal force. ${ }^{3}$

Empirically the cases of polygamous marriages have many implications not only for husbands or wives but also for children as a result of their marriage. The negative impact of polygamous marriage on children is related to their less successful education, the constant bickering between their father and mother, the lack of expenses from their father because their father's

and book III on Waqf. The contents of book I on Marriage Law consists of 19 chapters and 170 articles.

${ }^{3}$ UU no. 1 of 1974 article 3, and KHI article 56. 
dependents and expenses increased. These negative impacts cause the children to be neglected and inattentive. ${ }^{4}$ In other cases, polygamy harms children's mental development, especially for girls. ${ }^{5}$ There is a feeling of inferiority and avoiding associating with friends.

Several realities showed that the lives of polygamous women experience more in violence than happiness cases. National Commission on Women stated through its commissioner that in 2017 there were 1,697 cases of domestic violence due to polygamy ${ }^{6}$. The types of violence that occur exist in several contexts, such as emotional, economic, physical violence, including sexual violence. These indicate that women who live with husbands who have more than one wives are very vulnerable to acts of violence.

One of the essential things that are often overlooked in the discussions of polygamy is the social sanctions and penalties for violations and neglect by men against their wives and children. In this case, people sometimes remain silent and take it for granted. A polygamous man often abuses his wife and children, but they do not receive proper moral and social sanctions. It seems to have become a guarantee to prove the power and masculinity of men. Tragically, it is socially constructed that in society, there is proudness to have many wives and have acted arbitrarily toward the wives. The cases of neglecting child's rights in polygamous marriages are relevant to the protection of children right in the Indonesian Marriage Law Act Number 1/1974 and Islamic Compilation Law. It is crucial to analyze Islamic legal protection in Indonesian legal system, whether it is sufficient to protect

\footnotetext{
${ }^{4}$ Ridho Surya Chandara, SuatuKajian Yuridis Terhadap Perkawinan Poligami Pegawai Negeri Sipil di Kota Kota Medan (Case studyat religious court in Medan City), Tesis, 2004.

${ }^{5}$ Ratna Kusuma Wardaniand Idaul Hasanah, Pemenuhan Hak Anakdalam Keluarga Poligami, Jurnal Perempuandan Anak, Universitas Muhammadiyah Malang, in JPA UMM.ac.id, ${ }^{6}$ https://www.voaindonesia.com/a/komnasperempuan-praktik-poligami-adalah-kekerasanterhadap-perempuan/4702669.html
}

children in polygamous marriages or it is not sufficient to protect children from getting their rights as mandated in the provisions of the law on child protection.

\section{Methods}

The research method is a qualitative method, with socio-legal study case approach ${ }^{7}$. Secondary data were collected through desk research, while primary data are cases of families experiencing polygamous marriages. For case data collected through interviews. In primary data collection uses the technique of snowball sampling to get data from the subject. ${ }^{8}$ The collected data will then be analyzed using legal suitability analysis and families and children's sociological situation in polygamous marriages.

\section{Result and discussion}

In Islam, children are a mandate of Allah. After the birth of a child, even though he is still a toddler, he has rights. Some of the rights of children in Islamic teaching are the right of protection (QS. Annisa': 9), to live (QS. Al Isra; 31 ), to grow and develop (QS. Al Baqarah; 233), to get education and teaching (QS.. al-Tahrim: 6), to get livelihood and inheritance (QS. Annisa; 11), to have justice and equality (QS. An-Nisa':1279 and HR. Thabrani), to love and affection, to play according to his talent.

The children's protection in Islam aims to ensure children's rights to live, develop, and participate

\footnotetext{
${ }^{7}$ Reza Banakar and Max Travers (eds), Theory and Methods ini Socio Legal Research (Oxford and Portland Oregon: Hart Publishing, 2005). Peter Mahmud Marzuki, Penelitian Hukum, (Jakarta: Kencana Prenada Media Group, 2005). p. 87. Soerjono Soekantodan Sri Mamudji, Penelitian Normatif: Suatu Tinjauan Singkat, (Jakarta: Rajawali Perss, 1995),p. 14.

${ }^{8}$ Lexy J. Moleong, Metodologi Penelitian Kualitatif, (Bandung, Rosdakarya, 2010), p. 6

${ }^{9}$ Ministry of Religion of the Republic of Indonesia, Al-Quran and its Translation
} 
optimally following human dignity and protection from violence and discrimination. ${ }^{10}$

\section{Children's Rights in Islamic Marriage Law and Gap}

Act Number 1/1974 regulates children's rights in chapter nine concerning the position of the child and in chapter ten concerning the rights and obligations of parents and children.

A legitimate child is a child that born in or as a result of a legal marriage. ${ }^{11}$ The Children born in illegitimate marriage only have a civil relationship with their mother and their mother's family, and the position of the child will further be regulated in a Government Regulation. ${ }^{12}$

The next article stated that (1). Both parents are obliged to care for and educate their children as well as possible. (2). The parents' obligations apply until the child is married or is independent. This obligation applies even when the marriage between the two parents has divorced. ${ }^{13}$ This marriage law shows that children's regulated rights are the right to care for parents and the right to education. In the second part, the implementation of the parents' obligations to care for and educate their children is limited until the child is married or is independent. The rights of the child, which are also regulated in the same law, are the right to guarantee the fulfillment of life necessities and the right to be treated fairly by the parents of male children who choose to have a polygamous marriage. ${ }^{14}$

Based on an interview with the Head of the Office of Religious Affairs in the city of Medan, it was stated that basically the Marriage Law and its

10 Fatimah Zuhrah, The Fullfilment of children right in Poligamic Marriage in Medan City (an Analysis of Islamic Family Law), International Journal of Humanities and Social Sciences Invention (IJHSSI), ISSN (online: 2319-7722), ISSN (Print: 2319-7714) www. Ijhssi, org, Vol 6 issue 2, Desember 2017, PP 56-61.

${ }^{11}$ Act Number 1/1974 (Article 42):

${ }^{12}$ Act Number 1/1974 (Article 43)

${ }^{13}$ Act Number 1/1974 (Article 45)

${ }^{14}$ Act Number 1/1974 (Article 5, verse 1; b and c) derivative regulations or the Compilation of Islamic Laws regulating polygamous marriage are quite good. The challenge is in the implementation of regulations and compliance with the implementation of regulations ${ }^{15}$. However, the authors see many gaps in child protection in the KHI and the Marriage Law. If you pay attention to the marriage law, it does not regulate the concept of maturity. The concept of adult indicates that the adult boundaries set are "married", "independent", not yet 18 years old, not reaching 21 years of age. The concepts used in the Marriage Law do not provide legal certainty in determining indicators of a child's maturity. A child who has been married at the age of 15 (with the emergence of Law No. 16 of 2019 concerning amendments to Law No.1 of 1974 concerning marriage) will be forced to mature even though the child is biologically and psychologically immature. Likewise, the concept of "independent" in the Marriage Law is very relative. The concept of independence can mean being independent in the approach of property or material ownership. Also, being independent can be defined as being able to think carefully in considering good and bad. This emotional and intelligent maturity is also very relative in the context of age. The ambiguity of this concept can result in the implementation of the fulfillment of children's rights where parents can state that the child can stand alone, to release responsibility, but in the context of actual age, the child is still a child.

\section{Limitation on Child Rights Up to 18 years old or married}

As stated in the next article: Children who have not reached 18 (eighteen) years or have never been married are under the control of their parents as long as they are not removed from power. Parents represent their children regarding all legal actions inside and outside the Court. Parents are not allowed to transfer rights or duplicate property, which is owned by their children who are not yet 18 (eighteen) years old or have never been married, unless the child's interest so wishes.

\footnotetext{
${ }^{15}$ Interview with KUA Medan Tembung, 5 September 2019
} 
${ }^{16}$ Article 47 interprets that children before 18 are still under parental control as long as they are not married. If you look closely, this article is ambiguous with Article 6 paragraph (2) of the same Law, which states that to marry a person who has not reached the age of 21 (twenty-one) years must obtain permission from both parents. This article also interprets parental control over children. This ambiguity between article 6, paragraph 2, and article 47 does not provide legal certainty regarding the limits of parental control over children's lives, including control in fulfilling children's rights.

While parents who neglect their obligations toward his children, the law provides the following sanctions. As in stated in (article 49)

"One or both parents can be deprived of power over their child, at the request of the other parent, or the child's family in a straight line up or an adult sibling or an authorized official by a court decision in the following matters: a. parents have neglected their obligations towards their children; b. parents misbehave. Even though parents are deprived of their power, they are still obliged to provide care and support for the child". ${ }^{17}$

\section{The Protection of Children Right}

The protection of children's rights is regulated by law before a husband decides to do polygamy. As stated in (article 4 - 5) which contains rules regarding the requirements for obtaining permission to polygamy at the Religious Court.

When a husband will marry more than one wife he is obliged to submit an application to the Court in the area where he lives. Then the court only gives permission to a husband who will have more than one wife, whether if there is a reason that allows a husband to remarry. That reasons are:

a. the wife cannot carry out her obligations as a wife;

b. the wife has a disability or incurable disease;

c. the wife cannot born the offspring. ${ }^{18}$

\footnotetext{
${ }^{16}$ Act Number 1/1974 (Article 47 and 48)

${ }^{17}$ Act Number 1/1974 (Article 49)

${ }^{18}$ Act Number 1/1974 (Article 4)
}

Other requirements as stated in The Act Number $1 / 1974$ article 5 and operationalized in government regulation number 9 in 1975, namely: (a). requires the consent of the wife or wives both oral and written consent, if the agreement is an oral agreement, it must be pronounced before the Court Session;

(b) There is certainty that the husband is able to guarantee the living needs of his wife and children. With the following conditions: (i). There is a certificate regarding the husband's income signed by the workplace treasurer. (ii). there is an income tax certificate, (iii). there is another certificate that can be accepted by the court.

(c) There is a guarantee that the husband will be fair to his wives and children with a statement or promise from the husband made legally. ${ }^{19}$

Based on the explanation of the marriage law, the provisions regarding permission to polygamy in Islamic marriage law in Indonesia do not appear only to require a reason to merely observe the Islamic law as one of the conditions for a husband to be polygamous.

The requirements for the wife's permission and the existence of a guarantee of economic capability from the husband for his wives and children in a polygamous marriage are intended to improve the marriage institution and protect children. The existence of a written statement made by the wife and husband before the court guarantees that the husband can have his responsibility towards his wives and children.

In practice, polygamous marriages tend to hurt children, especially girls. From the 5 cases interviewed, children whose parents were married to polygamy became insecure, ashamed, and angry with their families and the environment. As one case was found in Medan Tembung, a child stated, "I hate seeing my father remarried, I don't want to accept my father again... I'm also ashamed of my school friends.. because I said that my father married an itchy widow... I'm embarrassed.. I'm sad to look Mom is the one who cries a lot ... that's why I'm lazy to go home quickly ... I'm stressed ... my mom is stupid ... I

\footnotetext{
${ }^{19}$ Government Regulation No. 9 of 1975
} 
don't know what to expect from dad ... even if there's no father we can still live..."20

However, the marriage law, which is also in the KHI and government regulations related to marriage, leaves a problem from the perspective of protecting and fulfilling children's rights. In the Child Protection Law Number 23 of 2002, which was later amended through Law Number 35 of $2014^{21}$, children are seen as legal subjects so that children's participation (in the Convention on the Rights of the child is called respect to the view of the child $)^{22}$ is a principle in the statute. Meanwhile, in the law, child marriage is placed as a legal object. Nothing is regulated in the Marriage Law, PP. 9 of 1975, and KHI that children should be asked for their opinion if the male parents want to have a polygamous marriage. So that in practice, religious judges never ask children about their parents' plans to conduct a polygamous marriage. This shows that the existing law does not pay attention to the best interests of the child.

On the other hand, the child's rights, which are regulated in Islamic law and in national law, are not regulated in detail in the existing marriage law, including in polygamous marriages. These unregulated rights include the right to protection, the right to love, the right to grow and develop, and the right to participate.

In the practice of implementing polygamous marriage in society, there are still many husbands who practice polygamy, ignoring these rules, even

\footnotetext{
${ }^{20}$ Results of interviews with the mother's daughter whose husband remarried in Medan Tembung ${ }^{21}$ Law Number 23 of 2002 concerning Child Protection which was later amended through Law Number 35 of 2014

${ }^{22}$ The Convention on the Rights of the Child is an international convention that regulates children's rights, adopted by the United Nations, and ratified by all countries in the world, except the United States. Indonesia ratified the Convention in 1990 through a presidential decree. The CRC has become a basic reference for Indonesia in formulating the Child Protection Law Number 23 of 2002 .
}

polygamous marriage without the wife's permission and marrying without a legal marriage /sirri marriage and without reporting to the court. Marriages that are not through legal marriage according to the country will become unregistered marriages. So then the civil rights of children are lost. Children remain the most vulnerable victims. This condition also causes child protection to be neglected and not a priority in a marriage, while the result of the marriage relationship is the presence of children.

The problem why many people do not comply with article 5 of Law 1 of 1974 and article 41 of government regulation number 9 of 1975 is because there is no criminal sanction for parties who violate both articles. Although guaranteed in the form of a certificate, husband's oral statement before the court, and a letter of agreement, when there was a violation of the agreement, there was no sanction arrangement imposed.

\section{Closing}

\section{Summary}

1. In the perspective of law number 1 of 1974 concerning marriage, a legitimate child is a child born from a legal marriage according to the law. Children born from illegitimate marriages only have a civil relationship with the mother and/or the mother's family.

2. According to Law 1/1974, the protection of children's rights in polygamous marriages is premarital. A husband, if he wants to submit to the court to be able to remarry, must meet the requirements of ensuring that the husband can guarantee the living needs of the wife and child their children. There is a guarantee that husbands will treat their wives and children lawfully.

3. There is a very interpretive conception in the marriage law, KHI, and also government regulations related to children's rights and polygamous marriage, especially regarding the conception of maturity, which relates to parental control

4. There is still a legal vacuum and gaps in Islamic legal protection of children's rights, especially in polygamous marriages such as the 
right to grow and develop, the right to love, and the right to participate

5. There is no criminal sanction for husbands who practice polygamy but do not comply with the agreement to be responsible for their children and wives who are made to practice polygamy.

\section{Recommendation}

1. It is important to make changes to the marriage law in line with the fulfillment of children's rights in Islamic law and national law, especially children's rights resulting from monogamous marriages and polygamous marriages.

2. The affirmation of the principle of monogamous marriage in the Marriage Law should be derived in a more binding regulation for parties wishing to have a polygamous marriage, including putting the principle of child participation in it.

3. Criminal sanctions should be emphasized for parties who violate the Marriage Law, especially the conditions for a polygamous marriage.

\section{References}

[1] Abdurrahman, 1992, Kompilasi Hukum Islam di Indonesia, Jakarta, Akademi Pressindo:.

[2] Government Regulation of the Republic of Indonesia, Number 9 of 1975 concerning Implementation of Law Number 1 of 1974 concerning Marriage

[3] Law Number 35 of 2014 concerning Amendments to Law Number 23 of 2002 concerning Child Protection

[4] Law Number 23 Year 2002 Concerning Child Protection

[5] Lexy J. Moleong, 2010, Metodologi Penelitian Kualitatif, Bandung, Rosdakarya.

[6] Ministry of Religion of the Republic of Indonesia, 2001, Al-Quran and Translation with Arabic-Latin Transliteration (Rumy), Semarang, Asy- Syifa,.

[7] Peter Mahmud Marzuki, 2005, Penelitian Hukum, (Jakarta: Kencana Prenada Media Group.
[8] Ridho Surya Chandara, 2004, Suatu Kajian Yuridis Terhadap Perkawinan Poligami Pegawai Negeri Sipil di Kota Kota Medan (Case study at religious court in Medan City), Thesis,.

[9] Ratna Kusuma Wardani and Idaul Hasanah, Pemenuhan Hak Anakdalam Keluarga Poligami, Jurnal Perempuandan Anak, Universitas Muhammadiyah Malang, in JPA UMM.ac.id,

[10] Reza Banakar and Max Travers (eds), 2005, Theory and Methods ini Socio Legal Research Oxford and Portland Oregon: Hart Publishing.

[11] Soerjono Soekanto and Sri Mamudji, 1995, Normative Research: A Brief Overview, Jakarta: Rajawali Perss,.

[12] Sugiyono, 2001, Quantitative Research Methods, Qualitative and R and D, Bandung Alfabeta,

[13] Zuhrah, Fatimah, The Fullfilment of children right in Poligamic Marriage in Medan City (an Analysis of Islamic Family Law), International Journal of Humanities and Social Sciences Invention (IJHSSI), ISSN (online: 2319-7722), ISSN (Print: 2319-7714) www. Ijhssi, org, Vol 6 issue 2, Desember 2017, PP 56-61.

[14] https://www.voaindonesia.com/a/komn as-perempuan-praktik-poligami-adalahkekerasan-terhadapperempuan/4702669.html 